\title{
A MANUFACTURING INDUSTRY FRAMEWORK THAT HAS IMPLICATIONS FOR THE LEAN ACCOUNTING
}

\author{
Mumpuni Wahyudiarti Sitoresmi*), Arry Eksandy \\ Accounting Department University of Muhammadiyah Tangerang \\ mumpuni.wahyudiarti@gmail.com
}

\begin{abstract}
This study aimed to examine the factors that affect application of lean accounting at Astra International, Tbk Group companies. This study used sample of Astra International, Tbk group companies that was selected by cluster random sampling base method. From the results of data obtained Astra Motor Components sub-sector was only sector companies that implemented lean accounting with the observational of 8 others subsector.Data analysis techniques used multiple linear regression analysis with IBM SPSS STATISTIC 24 program. The results of this study indicates that Continuous Improvement (CI) and Value Stream Cost (VSC) had positive and Value Stream Cost (VSC) had negative effect to implementation of lean accounting. But Just In Time (JIT) had no effect to implementation of lean accounting.
\end{abstract}

Keywords: Lean Accounting, Continuous Improvement (CI), Value Stream Cost (VSC), Balanced Score Card (BSC), and Just In Time (JIT).

\section{INTRODUCTION}

Companies that implement lean manufacturing have the goal of increasing value for customers by producing with quality excellent service and improve the profitability of the company through efficiency in every stage of the process. Customer demand in general is a short lead time so needs move quickly without having to wait long, without queuing, unnecessary large orders, excellent quality and affordable prices. Implementation of lean manufacturing can spur lean accounting needs. Because traditional accounting can not fill the needs of accounting practices in lean companies. For example in traditional accounting using analysis of variance for standard costing would encourage excessive production and this condition contradicts the demand-pull system required in lean manufacturing.

This study discusses the factors that affect the application of lean accounting at Astra International, Tbk Group companies. Lean accounting has the potential to change the structure of the economy in Indonesia. And expected to lead to positive socio-economic changes. Thus, it takes literature, research and development to support lean implementation in Indonesia. The concept expected not only be implemented in the manufacturing industry, but also in other sectors such as customer goods, banking, health or non-profit oriented companies. 


\section{LITERATURE REVIEW}

\subsection{Positive Accounting Theory}

The goal of positive theoretical approach to describe what and how financial information is presented and communicated to users of accounting information, the positive theoretical approach is not to suggest what accounting practices should be, but to explain why accounting practices achieve like their present state. In addition the positive theoretical approach strongly emphasizes the importance of empirical research to examine accounting theory that has been advanced in many accounting theory that has been advanced in many accounting theory literature can explain the prevailing accounting practices (Arif, 1999 in Indira, 2004).

\subsection{Stewardship Theory}

Stewardship theory is a theory that describes a situation which in managers just not motivated by individual goals but at their main outcome goal for the benefit of the organization, so this theory has a psychology and sociology base that has been designed where executives as stewards are motivated to act on principals, steward behavior will not leave the organization because steward trying to achieve the target organization. (Donaldson and Davis, 1989, 1991 in Raharjo, 2007).

\subsection{Lean Accounting}

Lean accounting approach designed to support and encourage of lean manufacturing. Lean manufacturing is all concepts and techniques aimed at simplifying business to the essential activities necessary to meet customer needs in a more effective and profitable way. (Brosnahan, 2008 in Sisdyani, 2010).

\subsection{Continuous Improvement}

Continuous Improvement $(\mathrm{CI})$ is an ongoing effort to develop and improve products, services, or processes. These efforts aim to find and get the "best way" of the resulting improvement, which provides the best solution to the problem, which results will persist and even grow better. Although the changes in'kaizen 'are not dramatic but few and gradual, the changes that are caused in a certain period of time are considerable. This is different from the changes generated by western management that are usually dramatic. (Womack \& Jones, 2003).

\subsection{Value Stream Cost}

Value streams include all activities, whether of value added or not, which is required since the product begins until the customer's hand. Value stream analysis waste to be identified and removed. Therefore lean manufacturing can have dramatic turnaround time and enable the production of small quantities with a variety of products.

\subsection{Balanced Scorecard}

The Balanced Scorecard (BSC) is an organization's framework for organizing and use it in strategies at all levels of the organization, initiatives and steps of an organizational strategy (Hoque and James, 2000). Ghosh and Mukherjee (2006) Argues that Balanced Scorecard (BSC) is a strategy management system that is not just a measuring tool, which helps organizations to explain their vision and strategy and turn it into action.

\subsection{Just In Time}

Just in time (JIT) is a sustainable and compelling problem-solving philosophy that supports lean production. It's production delivers costumers exactly as customers needs, without wastage, and with continuous improvement ( Heizer and Render, 2004). The main goal of 
just in time (JIT) is to improve the productivity by eliminating all of activities that have not added value (waste). Just in time (JIT) targets focus on continuous improvement (CI) to achieve lower production costs, higher productivity levels, quality and reliability better products, improving the delivery time of the final product and improve the working relationship between customers and suppliers (Kusumawati, 2009).

\subsection{Conceptual Framework}

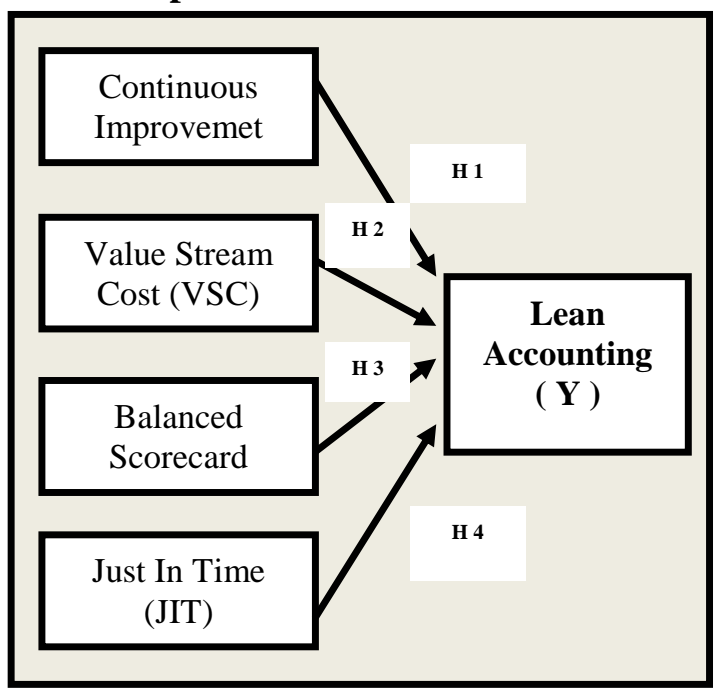

2.9 Measurement of Variables

\begin{tabular}{|l|l|c|}
\hline \multicolumn{1}{|c|}{ Variabels } & \multicolumn{1}{|c|}{ Indicator } & \multicolumn{1}{c|}{ Scale } \\
\hline Lean & 1. Specify Value & Linkert \\
Accounting & 2. Map the Value & \\
& Stream & \\
& $\begin{array}{l}\text { 3. Estabilish Flow } \\
\text { 4. Work to } \\
\text { Perfection }\end{array}$ & \\
& 5. Implement Pull & \\
\hline $\begin{array}{l}\text { Continuous } \\
\text { Improvement } \\
\text { (CI) }\end{array}$ & $\begin{array}{l}\text { 1. Quality } \\
\text { Commitment }\end{array}$ & Linkert \\
& $\begin{array}{l}\text { 2. Process } \\
\text { Orientation }\end{array}$ & \\
& $\begin{array}{l}\text { 3. Plan-Do-Chek- } \\
\text { Actual }\end{array}$ & \\
& 4. Talk by data & \\
\hline Value Stream & 1. Order & Linkert \\
Cost (VSC) & Completion & \\
& 2. New Products & \\
& 3. Marketing & \\
\hline
\end{tabular}

\begin{tabular}{|c|c|c|}
\hline $\begin{array}{l}\text { Balaced } \\
\text { Scorecard } \\
\text { (BSC) }\end{array}$ & $\begin{array}{l}\text { 1. Financial } \\
\text { Perspective } \\
\text { 2. Kosumen } \\
\text { Perspective } \\
\text { 3. Internal } \\
\text { Business } \\
\text { Perspective } \\
\text { 4. Growth } \\
\text { Perspectives }\end{array}$ & Linkert \\
\hline $\begin{array}{l}\text { Just In Time } \\
\text { (JIT) }\end{array}$ & 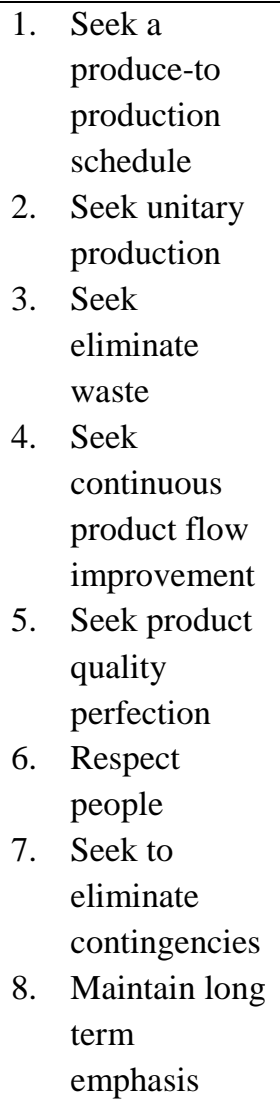 & Linkert \\
\hline
\end{tabular}

\section{RESEARCH METHOD}

\subsection{Population and Sample}

In this research use Cluster Random Sampling technique to analyze data. Cluster Random Sampling technique used when the population does not consist of individuals, but consists of individual groups or clusters (Sugiono 2004: 85). Astra International, Tbk group consisting of 8 sub-groups. And Astra Motor Components sub-sector, one of sector that implement lean 
accounting. Astra Motor Components sub-sector have 61,949 employees. So to know the sample research, with the calculation as follows:

$$
n=\frac{61949}{1+61949(0.1)^{2}}=99.83
$$

Adjusted to 100 Respondens.

\subsection{Data Collection Methods}

We are used primary data to obtained by distributing questionnaires to the employees of Astra International, Tbk that implemented Lean Accounting. The questionnaire was designed using Likert scale. Linkert scale for the first time introduced by Rensis Linkert in 1932. According to Sugiyono (2016; 93) "Likert scale is the scale used to measure attitudes, opinions, and perceptions of a person or group of people about social phenomena". Respondents were asked to provide an assessment of their views on the above 5 variables, using a Linkert scale of 1 to 5 , where 1 = Strongly Disagree (SD), 2 =
Disagree (D), $3=$ Less Agree (LA), $4=$ Agree (A), $5=$ Strongly Agree (SA).

\subsection{Data Analysis Technique}

Data analysis technique used is multiple linear regression analysis with IBM SPSS STATISTIC 24. And this in an formulas of multiple linear regression analysis :

$$
\begin{aligned}
& \mathrm{Y}=\boldsymbol{\alpha}+\boldsymbol{\beta}_{1} \cdot \mathrm{CI}+\boldsymbol{\beta}_{2} \cdot \mathrm{VSC}+\boldsymbol{\beta}_{3} \cdot \mathrm{BSC}+ \\
& \boldsymbol{\beta}_{4} \cdot \mathrm{JIT}+e
\end{aligned}
$$

Information :

$\mathrm{Y}=$ Lean Accounting

$\alpha=$ Interception Constants

$\beta=$ Regression coefficient

$e=$ standard error

\section{RESULTS AND DISCUSSION}

\begin{tabular}{|c|c|c|c|}
\hline Variable & Validity & Reliability & Criteria \\
\hline Lean Accounting ( Y ) & $100 \%$ & .648 & Valid \& Reliable \\
\hline Continuous Improvement (X1) & $100 \%$ & .832 & Valid \& Reliable \\
\hline Value Stream Cost (X2) & $100 \%$ & .860 & Valid \& Reliable \\
\hline Balanced Score Card (X3) & $100 \%$ & .899 & Valid \& Reliable \\
\hline Just In Time (X4) & $100 \%$ & .860 & Valid \& Reliable \\
\hline
\end{tabular}

\subsection{Test Instruments}

Table 1 : Validity and Reliability Test

Source : self proceed

\subsection{Classic Assumption Test}

\subsubsection{Normality Test}

The residual of normality test aims to determine approximates of normal distribution. In this study the researchers used kolmogorov-smirnov test by looking at the value of kolmogorov smirnov-Z and its Asymp.Sig value. 
Table 2 : Normality Test

One-Sample Kolmogorov-Smirnov Test

Unstandardized Residual

\begin{tabular}{lll}
\hline $\mathrm{N}$ & & 100 \\
\hline Normal Parameters $^{\mathrm{a}, \mathrm{b}}$ & Mean & .0000000 \\
\cline { 2 - 3 } & Std. Deviation & 1.96583371 \\
\hline Most Extreme Differences & Absolute & .096 \\
\cline { 2 - 3 } & Positive & .096 \\
\cline { 2 - 3 } & Negative & -.063 \\
\hline Test Statistic & & .096 \\
\hline Asymp. Sig. (2-tailed) & & $.023^{\mathrm{c}}$ \\
\hline
\end{tabular}

Source : self proceed

Based on these test results, sig value. equal to 0.023 or less than $\alpha 0.05$ this indicates that the test results are not eligible. Thus, we need transformation data to natural logarithm for dependent variable and independent variable. The result of the residual normality test after the data is transformed is as follows:

Table 3 : Normalitas Test

One-Sample Kolmogorov-Smirnov Test

Unstandardized Residual

\begin{tabular}{lll}
\hline N & & 100 \\
\hline Normal Parameters $^{\mathrm{a}, \mathrm{b}}$ & Mean & .0000000 \\
\cline { 2 - 3 } & Std. Deviation & .05712065 \\
\hline Most Extreme Differences & Absolute & .085 \\
\cline { 2 - 3 } & Positive & .085 \\
\cline { 2 - 3 } & Negative & -.051 \\
\hline Test Statistic & & .085 \\
\hline Asymp. Sig. (2-tailed) & & $.075^{\mathrm{c}}$ \\
\hline
\end{tabular}

Source : self proceed 
Based on the results, it can be deduced that the data is normally distributed. This is indicated by the value of Kolmogorov-Smirnov of 0.075 which is greater than 0.05 . It is means that the residual data is normally distributed, the significance value is more than 0.05 .

\subsubsection{Multicolinearity Test}

Table 4 shows VIF value below 10 and Tolerance value is not less than 0.1 , its means that among independent variables in this study have no relations with each other. so it can be concluded that the regression model does not have Multicollinearity.

Table 4 : Multicolinearity Test

Coefficients $^{a}$

\begin{tabular}{|c|c|c|c|c|c|c|c|c|}
\hline \multirow[b]{2}{*}{ Mo } & & \multicolumn{2}{|c|}{$\begin{array}{l}\text { Unstandardized } \\
\text { Coefficients }\end{array}$} & \multirow{2}{*}{$\begin{array}{c}\text { Standardize } \\
\mathrm{d} \\
\text { Coefficients } \\
\text { Beta }\end{array}$} & \multirow[b]{2}{*}{$\mathrm{T}$} & \multirow[b]{2}{*}{ Sig. } & \multicolumn{2}{|c|}{ Collinearity Statistics } \\
\hline & & B & $\begin{array}{l}\text { Std. } \\
\text { Error }\end{array}$ & & & & Tolerance & VIF \\
\hline \multirow[t]{5}{*}{$\overline{1}$} & (C) & 18.612 & 2.655 & & 7.011 & .000 & & \\
\hline & CI & .539 & .103 & .633 & 5.239 & .000 & .478 & 2.094 \\
\hline & VSC & -.242 & .110 & -.383 & -2.204 & .030 & .230 & 4.342 \\
\hline & BSC & .244 & .109 & .398 & 2.242 & .027 & .221 & 4.523 \\
\hline & JIT & -.087 & .095 & -.112 & -.912 & .364 & .458 & 2.184 \\
\hline
\end{tabular}

Source : self proceed

\subsubsection{Heteroscedasticity Test}

Table 5 : Heteroscedasticity Test

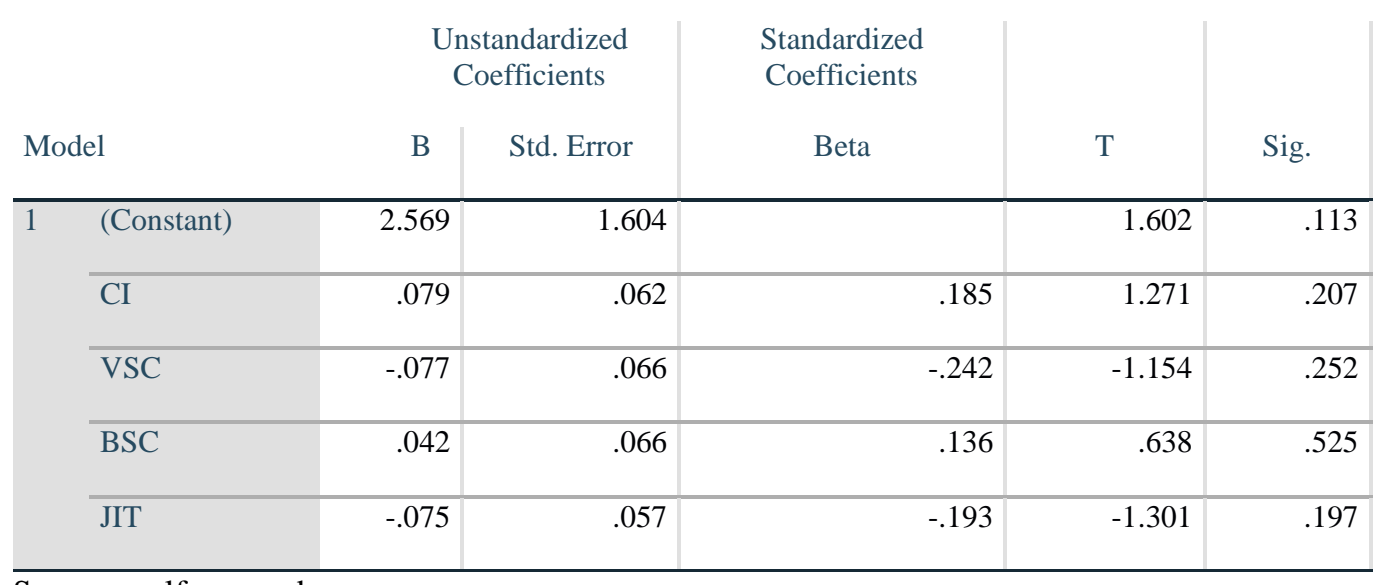

Source : self proceed 
From this test result, show us that all of than 0.005 . variables $\mathrm{x}$, has significant value more

\subsection{F Test}

Tabel 6 : F Test

ANOVA ${ }^{a}$

\begin{tabular}{|c|c|c|c|c|c|c|}
\hline \multicolumn{2}{|c|}{ Model } & Sum of Squares & Df & Mean Square & F & Sig. \\
\hline \multirow{3}{*}{1} & Regression & 195.574 & 4 & 48.894 & 12.141 & $.000^{\mathrm{b}}$ \\
\hline & Residual & 382.586 & 95 & 4.027 & & \\
\hline & Total & 578.160 & 99 & & & \\
\hline
\end{tabular}

Source : Self Proceed

Based of test results, shows the value of $\mathrm{F}$ arithmetic is 12.141 and the value of Sig. of anova table is 0.000 . We compare the $\mathrm{F}$ arithmetic with $\mathrm{F}$ table is by using formula $(\mathrm{k} ; \mathrm{n}-\mathrm{k}) . \mathrm{K}$ is the number of independent variables, and $n$ is the number of respondents or research samples. In this study, the independent variables studied are 4 , and $\mathrm{k}=4$, the number of respondents is 100 . Then $(\mathrm{k}$; nk) is $(4 ; 100-4)$. F table for $(4 ; 96)$ that is equal to 2.47. It is seen that the value of $\mathrm{F}$ arithmetic is greater than $\mathrm{F}$ table which means there is influence between independent variable together to dependent variable.

\subsection{Coefficient of Determination Analysis $\left(\mathbf{R}^{2}\right)$}

$\mathrm{R}$ Square value in this test is 0.310 . This means that the variation of the dependent variable that can be explained by the independent variable is $31 \%$, while the rest of $69 \%$ is explained by other variables not included in the regression model.

Table 7 : Coefficient Determination analysis.

\begin{tabular}{cc|c|c|c}
\multicolumn{9}{c|}{ Model Summary $^{\mathbf{b}}$} \\
Model & $\mathrm{R}$ & $\mathrm{R}$ Square & Adjusted R Square & $\begin{array}{c}\text { Std. Error of the } \\
\text { Estimate }\end{array}$ \\
\hline 1 & $.582^{\mathrm{a}}$ & .338 & .310 & 2.00679 \\
\hline & & & & \\
\hline
\end{tabular}

Source : Self Proceed 
Based on table 8, continuous Improvement (X1) has t count equal to 5,239 which mean bigger than t table equal to 1,988 . and a Sig value of 0.000 which means smaller than the significance level of 0.05 . it can be concluded that $\mathrm{H} 1$ received that indicates that Continuous Improvement (X1) has a positive effect on Lean Accounting (Y). From the calculation, Value Stream Cost (X2) has t count equal to -2.242 which means smaller than $\mathrm{t}$ table equal to 1,988 . and the $\mathrm{Sig}$ value of 0.030 which means smaller than the significance level of 0.05 . it can be concluded that $\mathrm{H} 2$ received that indicates that Value Stream Cost (X2) has a negative effect on Lean Accounting (Y).

From the calculation, work experience variable has $t$ count equal to 2,242 which mean bigger than $t$ table equal to 1,988 . and the $\mathrm{Sig}$ value of 0.027 which means smaller than the significance level of 0.05 . it can be concluded that $\mathrm{H} 3$ accepted that shows that Balanced Score Card (X3) have positive effect on Lean Accounting (Y).

From the calculation, work experience variable has t count equal to , 912 which means smaller than $t$ table equal to 1,988. and the Sig value of 0.364 which means greater than the significance level of 0.05 . it can be concluded that $\mathrm{H} 4$ is accepted indicating that Just In Time (X4) has no effect on Lean Accounting (Y).

\subsection{Multiple Linear Regression Analysis}

$\mathrm{LA}(\mathrm{Y})=18.612+0,539 . \mathrm{CI}-$ 0,242.VSC + 0,244.BSC - 0,087.JIT +

Source: Self processed

From the multiple linear regression equation above obtained a constant value of 18.612. That is, if the lean accounting (Y) variable is not affected by independent variables it have value 18.612. The value of the regression coefficients in the independent variables illustrates if the estimated independent variables increase by one unit and the value of other independent variables is estimated to be constant or equal to zero, then the value of the dependent variable is expected to rise or may decrease in accordance with the coefficient sign of the independent variable regression.

The regression coefficient for independent continuous improvement (X1) variable is positive, indicating a direct relationship between continuous improvement (X1) and lean accounting (Y). The regression coefficient of variable $\mathrm{X} 1$ of 0,539 means that if continuous improvement (X1) is 0 , then lean accounting $(\mathrm{Y})$ is 18.612. And to increase the value of continuous improvement (X1) for one unit will cause the increase of lean accounting (Y) to 19,151. The regression coefficient for value stream cost independent variable (X2) is negative, indicating the existence of the opposite relationship between value stream cost (X2) and lean accounting (Y). The regression coefficient of variable $\mathrm{X} 2$ of -0.242 means to decrease the value stream value value (X2) for one unit will cause the increase of lean accounting (Y) value of one unit to 18,854 . The regression coefficient for the independent variable Balanced Score Card (X3) is positive, indicating a direct relationship between Balanced Score Card (X3) and lean accounting (Y). The regression coefficient of variable $\mathrm{X} 1$ of 0.244 means if Balanced Score Card (X3) is 0 , then lean accounting (Y) 18,612. And to increase the value of Balanced Score Card (X3) for one unit will cause the increase of lean accounting (Y) to become 18,856. Regression coefficient for free variable Just In Time (X4) equal to 0,242, with significance equal to 0,364 . Whether or 
not an increase of one unit variable of Just In Time (X4) will not affect the value of the Lean Accounting (Y) constant. Because in this study variable Just In Time (X4) has no effect on Lean Accounting (Y).

\section{CONCLUSION}

The implementation of Continuous Improvement (CI) should be improved to support lean culture that is expected to be one of the supporting factors to achieve company objectives. One of them is by supporting and promoting the Quality Control Circle (QCC). Always be consistent in the use of Value Stream Cost (VSC) in determining the cost of the product, so it can always present more actual cost information, since the cost allocation element has been minimized. Companies are advised to pay more attention to Balanced Scorecard perspectives (BSC). In this research we found that indicators of BSC perspectives had the lowest average results. This means that less attention to these indicators within the company. Therefore, the application of indicators of BSC perspectives need to be optimized for the achievement of corporate objectives. We all know that Just In Time (JIT) is the key to Toyota's success in implementing lean thingking or what we know about TPS. However, in this study JIT variables become ineffective application to PT. Astra International, Tbk Group. After more indepth analysis, there are several things that need to be improved so that the use of JIT can affect the application of lean accounting as one of the philosophy for the progress of the company, among others:

a. Improve JIT failure on internal systems, by training employees.

b. Establish and develop suppliers by engaging together for the benefit of both parties in long-term business relationships.

c. Have at least 2 suppliers in each value stream. This is intended to facilitate the process of cost analysis, negotiation and tender in the process of purchasing goods / services.

d. Optimizing vendor management sections to maintain supply chain to avoid supplier delay which will have adverse impact on JIT implementation.

\section{REFERENCES}

Algifari. (2015). Analisis Regresi untuk Bisnis dan Ekonomi. Yogyakarta: BPFE Press.

Anton, FX. (2010). Menuju Teori Stewardship Manajemen. Majalah Ilmiah Informatika Volume. 1 No.2 Fakultas Ekonomi Universitas AKI Semarang.

Beverley, R. L., Yvonne, P. S., dan Michelle, J. G., (2005). The Balanced scorecard : a New Zeeland Perspective. Pasific accounting review, Vol 17(1).

Cunningham, J., \& Jones, D. (2007). Easier, Simpler, Faster: Systems Strategy for Lean IT. New York, NY: Productivity Press.

Emiliani, B. (2007). Better Thinking Better Results. CLBM, 2nd ed. USA: Whethersfield.

Enoch, O. K. (2013). Lean Accounting and Lean Business Philosophy in Nigeria: An Exploratory Research. International Journal of Economics, Finance and Management.

Fullerton, R. R et al. (2013). Management accounting and control practices in a lean manufacturing environment. Organizations and Society 38.

Ghosh, S. dan Mukherjee, S. (2006). Measurement of Corporate Performance Through Balanced Scorecard : An Overview. 
Vidyasagar University Journal of Commerce, Vol. 11.

Hoque, Z. dan James, W. (2000). Thinking Balanced Scorecard Measures to Size and Market Factor : Impact on Organizational Perfomance. Journal of Management Accounting Research, Vol. 12.

Jauarti, Indira.(2004). Pendekatan dan Kritik Teori Akuntansi Positif. Jurnal Akuntansi dan Auditing Fakultas Ekonomi UNDIP Vol. 01/No. 01.

Kaplan, R. S., Norton, D. P., (2001). The Strategy-focused organization: how $B S C$ companies thrive in the new competitive environment.

Kumar, M. \& Antony, J., (2009). Multiple case- study analysis of quality management practice within UK six sigma and non-six sigma manufacturing small- and mediumsized enterprises, Journal of Engineering Manufacture.

Kusumawati, Ratna. (2009). Studi Just In Time untuk Meningkatkan Kinerja Produktivitas Perusahaan. AKSES: Jurnal Ekonomi dan Bisnis Vol. 4 No. 8, 2009.

Liker, K. Jeffrey. (2006). The Toyota Way, Indonesia Edition. Jakarta:Erlangga.

Maskell, B., Baggaley, B., \& Grasso, L. (2011). Practical Lean Accounting: A Proven System for Measuring and Managing the Lean Enterprise. Boca Raton, FL: CRC Press.

Nigel, E., (2005). Assesing the Balanced Scorecard as a Management Tool for Hotel. International Journal of Contemporary Hospitality Management, Vol. 17(5).

Radnor, Z., Walley, P., tephens, A., and Bucci, G. (2006). Evaluation of the Lean Approach to Business Management and Its Use in the Public Sector. Scotland University.

Raharjo, Eko. (2007). Teori Agensi dan Teori Stewarship dalam Perspektif
Akuntansi, Jurnal Fokus Akuntansi Vol. 2 No. 1.

Rao, M., \& Bargerstock, A., (2011). Exploring the Role of Standard Costing in Lean Manufacturing Enterprises: A Structuration Theory Approach. Management Accounting Quarterly.

Rosa, A., \& Machado, M. (2013). Lean Accounting: Accounting Contribution for Lean Management Philosophy. In Proceedings of the Tourism and Management Studies International Conference Vol. 3. Algarve, Portugal: University of Algarve.

Sisdyani, E.A.,(2010). Lean Accounting : Suatu Alternatif Teknik Akuntansi Manajemen dalam Industry Manufaktur, Jurnal Akutansi Fakultas Ekonomi Universitas Udayana.

Sugiono. (2016). Metode Penelitian Kuantitatif Kualitatif dan $R \& D$.Bandung: Alfabeta.

Tjahjadi., (2001). JIT Purchashing, JIT Production Systems:Pengaruhnya terhadap Kineja Produktivitas.

Timm, P. H., (2015). Perceptions of Value-Stream Costing and the Effect on Lean-Accounting Implementation, Walden Dissertations and Doctoral Studies.

Wahdiat, I. S., (2016). Analisys of Lean Accounting, JIT and Balance Scorecard in the Company's Lean Manufacturing. International Journal of Scientific \& Technology Research Vol.5, Issue 02.

Womack, J.P., Jones, D.T., (2003). Lean Thinking. USA: Free Press Production \& Colophon Simon \& Schuster, Inc.

Womack, J.P., Jones, D.T., Roos, D., (2003). The Machine That Changed the World: The Story of Lean Production. USA:Free Press Production \& Colophon Simon \& Schuster, Inc. 